\title{
Erratum to: Stability of a Two-Layer Silicene on a Nickel Substrate upon Intercalation of Lithium
}

\author{
A. Y. Galashev ${ }^{a, b}, *$ and O. R. Rakhmanova ${ }^{a, b}$ \\ ${ }^{a}$ Institute of High-Temperature Electrochemistry, Ural Branch, Russian Academy of Sciences, Yekaterinburg, 620990 Russia \\ ${ }^{b}$ Ural Federal University, Yekaterinburg, 620002 Russia \\ *e-mail: alexander-galashev@yandex.ru \\ Received September 22, 2020; revised September 22, 2020; accepted September 22, 2020
}

DOI: $10.1134 / \mathrm{S} 108765962030001 \mathrm{X}$

The title of the article should read as follows:

Stability of a Two-Layer Silicene on a Nickel Substrate upon Intercalation of Lithium.

Corresponding author of the article and his e-mail should read as follows:

A.Y. Galashev; e-mail: alexander-galashev@yandex.ru.

The original article can be found online at

https://doi.org/10.1134/S1087659620040069 